\title{
Productivity of Islamic Banking in Indonesia
}

\author{
Fajra Octrina $^{1 *}$; Alia Gantina Siti Mariam² \\ ${ }^{1}$ Faculty of Economics and Business, Universitas Telkom, Indonesia \\ ${ }^{2}$ Business Administration Study Program, Politeknik LP3I Bandung, Indonesia. \\ *To whom correspondence should be addressed.Email: octrinafajra@gmail.com
}

\begin{tabular}{|l|l|l|l|l|}
\hline DOI: & Received: & Revised: & Accepted: & Published:
\end{tabular}

\begin{tabular}{|l|l|l|l|l}
$10.22437 / p p d . v 9 i 1.11041$ & 14.11 .2020 & 26.01 .2021 & 27.02 .2021 & 30.04 .2021 \\
\hline
\end{tabular}

\begin{abstract}
One measurement tool to increase banking performance, especially Islamic banking, is from the productivity side. Productivity measurement is done to determine how far a bank can run its operational activities by minimalizing input and maximalizing output results. This study aims to analyze the productivity level of Islamic Banking in Indonesia. The research sample was 11 Islamic banks from 2010 to 2019. Data obtained through financial statements and then divided into input and output variables. The productivity measurement technique by using Malmquist Index. The research shows that Islamic banking productivity with a cost approach indicates that Islamic banking has achieved a productive stage. It is seen from the average TFPCH (Total Factor Productivity Change) score that is quite high. It indicates that the decrease in Indonesia's Islamic banking growth generally occurs due to technology change.
\end{abstract}

Keywords: Islamic Banking, Malmquist Index Productivity, Productivity

JEL Classification: C67, G21

\section{INTRODUCTION}

Officially Islamic Bank emerged in 1992 with PT. Bank Muamalat Indonesia (BMI), which The Council of Indonesian Ulama (Majelis Ulama Indonesia, MUI). Law No 7, the Year 1992 concerning Banking, states that Islamic Bank is a bank with a profit-sharing system, without any detailed explanation about Syariah law or business type. Completion of the law is carried out through Law No. 10 of 1998 concerning Amendments to Law No. 7 of 1992 concerning Banking. The law explicitly explains the dual banking system, namely the conventional banking system and the Islamic banking system.

Since the emergence of Islamic banking, many improvements are achieved from the institutional side, regulation and monitoring systems have continuously improved. Besides that, more support in the form of Islamic finance literature continuously grows in society. The rapid development of the Islamic banking industry in the last couple of years indicates that society has been aware of Islamic banking. However, in the middle of the rapid development and people awareness, it doesn't close the possibility that there are still some people who aren't aware of the system and benefit of Islamic banking.

In October 2019, Islamic Bank development can be seen from Islamic banking's 
total savings that reach 31,89 million. The Third Party Fund (Dana Pihak Ketiga/DPK) reaches RP 402,36 trillion, and total funding is 345,28 trillion. However, such an amount of DPK funds then raises a question of whether the bank has productively carried out its operational activities.

The Islamic banking industry's development becomes one of the main indicators in developing the Islamic financial economy. Because of this condition, research must be done in terms of how Islamic banking manages its input as minimal as possible to produce maximal output. On that basis, it needs to research how productive Islamic banking is in managing input and output.

Based on that condition, a problem appears, which becomes the basis of why this research is done; that is how the productivity level. The objective expected is to study efforts that an Islamic bank must do to increase productivity. This research becomes important because research about Islamic bank productivity is still rare; therefore, this research must be done immediately to have good performance and compete with a conventional bank.

A literature study states that even though many studies about banking efficiency level, research about productivity is still rare, as Rani, Widiastuti, \& Rusydiana (2018) research productivity level using Malmquist Index is rare in Indonesia banking literature study. Moreover, research about productivity will be done using the Malmquist Index Productivity (MPI) method, a part of the Data Envelopment Analysis (DEA) method to see each business unit's productivity level in each business unit.

This research aims to measure Islamic banks' productivity levels in Indonesia using the MPI test during the 2010-2019 period. In brief, the research question is how is Islamic banks' performance in Indonesia during the research period?

Novelty contribution in this research is seen in several things. First, this research includes a new period, especially when Islamic banks grew rapidly in Indonesia. Second, this research is different from the previous study related to input and output usage; third, there isn't much research about productivity using Malmquist Productivity Index in Islamic banking in Indonesia.

Hopefully, this research can add knowledge about the Islamic banking industry for researchers themselves and other parties, in this case, society. Hopefully, this result can give a conceptual contribution to the development of knowledge and research in the financial field, especially Islamic banking. It can give the government an idea contribution for Financial Service Authority (OJK) and Bank Indonesia. Besides that, this research uses the intermediation approach because the intermediation approach is a more appropriate approach to evaluating banking performance because its main function is to collect and dispense funds from society, seen in the used variables.

Islamic banking potential in Indonesia can be said growing; until 2019, there are 14 Islamic banks with 20 Islamic Business Units. In 2019 Islamic Finance Country Index (IFCI) also stated that the Indonesian Islamic banking rank was in no 1, passed Malaysia. Upon that escalation, therefore Islamic bank in Indonesia is expected to manage input and output more productive.

MPI is a method that uses DEA to evaluate productivity changes between two points by calculating ratio score of increase and decrease between two periods Coelli, Rao, O'Donnell, \& Battese (2005). MPI is used to compare input and output in production concepts. This index was first introduced in 1953 by the MPI method with DEA basis was first introduced by Cavest al. in 1982, which was empirically developed by Fare in 1992 and 1994. Overall, there are three different alternatives in evaluating 
productivity changes: the Fisher Index in 1922, the Tornqvist Index in 1936, and the Malmquist Index (1953). The Malmquist index is a non-parametric index. The Fischer and Tornqvist index are parametric indices; both indexes have variations in behavior assumption and whether they recognize random mistakes in data or noise (Kamarudin, Hue, Sufian, \& Anwar, 2017).

Malmquist Index involves Technical Efficiency Change variables (EFFCH), Technology Change (TECHCH), Pure Technical Efficiency Change (PECH), Efficiency Scale Change (SECH), and Productivity Factor Total Change (TFPCH) (Raphael, 2013). The result from the Total Productivity Factor (TFPCH) Malmquist Index is measured by multiplying Technical Efficiency Change (EFFCH) with Technology Change (TECHCH).

Färe et al. (1994), Sellers-rubio \& Mas-ruiz (2007), Malmquist Index can be formulated as follows:

$$
M_{t, t+1}\left(y^{t+1}, x^{t+1}, y^{t}, x^{t}\right)=\left(\frac{D^{t}\left(y^{t+1}, x^{t+1}\right)}{D^{t}\left(y^{t}, x^{t}\right)} \frac{D^{t+1}\left(y^{t+1}, x^{t+1}\right)}{D^{t+1}\left(y^{t}, x^{t}\right)}\right)^{1 / 2}
$$

I is indicated as output orientation, $\mathrm{M}$ is productivity from the previous production period $\left(\mathrm{x}^{\mathrm{t}+1}, \mathrm{y}^{\mathrm{t}+1}\right)$ using $\mathrm{t}+1$ period technology, in correlation with the previous production period $\left(\mathrm{x}^{1}, \mathrm{y}^{1}\right)$ using t period technology, $\mathrm{D}$ is an input distance function.

$$
M_{t, t+1}\left(y^{t+1}, x^{t+1}, y^{t}, x^{t}\right)=\frac{D^{t}\left(y^{t+1}, x^{t+1}\right)}{D^{t}\left(y^{t}, x^{t}\right)}\left(\frac{D^{t}\left(y^{t+1}, x^{t+1}\right)}{D^{t+1}\left(y^{t+1}, x^{t+1}\right)} \frac{D^{t}\left(y^{t}, x^{t}\right)}{D^{t+1}\left(y^{t}, x^{t}\right)}\right)^{1 / 2}
$$

Or $\mathrm{M}=\mathrm{E} . \mathrm{P}, \mathrm{M}$ is Malmquist index from the measurement of $\mathrm{P}$ technical process which is measured as frontier period $t+1$ and period $t$ with $E$ efficient change at the same time.

There are several reasons why this Malmquist index is better than other methods in measuring productivity. According to Griffel-Tatje, E., and Lovell (1996) and Suzuki \& Sastrosuwito (2011), the Malmquist Index has three main advantages compared to Fisher and Tornqvist Index. First, it doesn't require profit maximization and cost minimization. Second, it doesn't need information about input and output prices. Third, if the researcher has panel data, it analyzes productivity into two components: technical efficiency change or catching up and technical change or change in the best practice. However, besides advantages, the Malmquist index also has a disadvantage: thee needs to count distance function, but the DEA technique can overcome this problem.

Some research related to productivity, as Kumbhakar and Lovell (2000) stated, stated that technical efficiency is one of economy efficiency components as a whole, in which corporation is expected to be technically efficient. If efficiency is done to increase profit, the corporation must have maximal output with specific inputs with a specific price level. Avenzora et al. (2008) stated that productivity could be measured partially, which observes the relation between output and several aggregate inputs. If the number of inputs increases, then more output will be produced.

Sufian (2007) researched productivity index difference, technology change, efficiency change, and efficiency scale. Research result shows that middle-sized Islamic banks in Malaysia have higher productivity because of more advanced technology. Moreover, Sufian (2009) did banking research in Malaysia from 2001-2004. Research result indicates that Islamic bank experienced an $8.4 \%$ productivity increase in 2020 and got the highest score in 2003 as big as $11.2 \%$, but experienced a decline in 2004 with 4.6\% value. Besides, research result also indicates that foreign banks show higher 
productivity than domestic banks in the early years of research. The opposite results in domestic banks' productivity relatively higher than those of foreign banks in the last years of research.

Inversely proportional to Raphael's (2013) finding, which examined the banking productivity level in Tanzania, this result indicates that efficiency change from a big scale domestic bank is bigger than that of another scale group. Meanwhile, small-scale banks' productivity value tends to be higher than big scale banks or big scale foreign banks. Research result by Octrina et al. (2019) indicates that a big bank is not necessarily more productive than a small bank.

Neupane (2013) did banking research in Nepal, and research result indicates that bank productivity increase because of technical factor and not because of efficiency influence. This result is different from what was done by Kalluci (2018) that indicates banking productivity value in Albania is affected by efficiency level, driven by efficiency scale and pure efficiency, not because of technological change. Meanwhile, productivity growth is averagely higher in middle-scale banks compare to other scales. According to Basri et al. (2018), one of the most influential factors for the Malmquist Productivity Index is technology change as the most influential factor towards growth. Along with technology advancement then this factor also has a major role in increasing banking performance from the productivity side.

Suzuki \& Sastrosuwito (2011) researched 70 banks in Indonesia during 19942008 found that general bank productivity change in Indonesia was affected by technological change and not because of technical efficiency change. This finding implies the importance of technology development in creating productive banking. Meanwhile, Hadad, Hall, Kenjegaliev, Santoso, \& Simper (2011), in their research, indicates that the average banking productivity in Indonesia is stable in which the most influential factor is technology advancement. According to Octrina et al. (2020), Indonesian banking tends to be more productive during the 2005-2016 period, with output used is the total of bank loan, securities investment, and other income, but from the efficiency change side Technical Efficiency Change Scale Efficiency Change aren't optimum yet.

Research about Islamic bank productivity using the Malmquist index hasn't been done yet, especially in Indonesia, compared to conventional bank research. But several types of research related to Islamic bank productivity have been done, amongst is Abbas did research uses DEA method and Malmquist index in Islamic banking in Pakistan during 2005-2009 indicates that bank productivity is higher in 2005 until 2006 and 2008-2009. Research related to Islamic banking productivity also done by Yildirim (2015) on Islamic banking in Turkey and Malaysia, research result shows that bank productivity isn't affected by technical Efficiency Change (EFFCH). This result indicates that bank managerial efficiency hasn't been able to do banking activity properly. Meanwhile, technology change is considered better even though the TFPCH hasn't reached the optimum score.

Kamarudin, Hue, Sufian, Anwar, \& Aina (2017) researched 2006-2014 to examine the productivity of 29 Islamic banks in Southeast Asia. Research indicates that the increase of EFFCH technical efficiency becomes the most influential factor in the productivity level of domestic or foreign banks. Other research by Basri, Muhamat, \& Jaafar (2018) on Domestic and Foreign Islamic Banks (IBs) in Malaysia discovers the most inefficient bank based on DEA test has increased in technical efficiency, technology change, and the total productivity factor based on MPI test. Usman, 
Andriyani, \& Pambuko (2019) did non parametric MPI test during 2012-2017 on nine Islamic banks in Indonesia. Research result indicates that the increase in productivity is more affected by technology aspect, not efficiency, the social fund increases $8.2 \%$ and more productive than a financial fund that decreases by $5.4 \%$.

Besides, many research results indicate that the increase or decrease of productivity impacts technology advancement, Therefore further research is needed about how the condition of Islamic banking efficiency. This research result is expected to give stakeholders, especially the board of Islamic bank superintendent, to supervise and guide to increase productivity.

\section{METHODS}

This research uses secondary data in panel data or longitudinal data, a group of individual data consisting of Islamic general bank data in Indonesia. Data is obtained from Bank Financial report, which is reported to bank Indonesia, Financial Service Authority, and several data obtained from bank websites.

The research was done during 2010-2019. The population in this research is all Islamic Bank in Indonesia with a total of 14 banks. But in sample determination was done by purposive sampling method with criteria active bank during the research period, 11 banks. Data analysis that is used is descriptive analysis to describe studied variable, which is productivity, with analysis tool using computer program Deap 2.1.

This research is quantitative research using input and output variables to test productivity levels. Input and output that are used are general and administrative cost, fixed asset, total saving as input variables. Output variables are total loan, securities investment, and other income (Table 1).

Table 1. Productivity input variable and output variable

\begin{tabular}{ll}
\hline \multirow{3}{*}{ Input Variable } & General and Administrative Cost \\
& Fixed Asset \\
& Total Saving \\
\hline \multirow{3}{*}{ Output Variable } & Total Loan \\
& Securities Investment \\
& Other income \\
\hline
\end{tabular}

\section{RESULTS AND DISCUSSION}

To analyze the productivity growth level of General Bank in Indonesia, uses Malmquist Total Factor Productivity Index (MTFPI) approach. Total productivity, usually called Total Factor Productivity (TFP), measures output with several inputs together. The relation is stated in the ratio from the output index towards the aggregate input index. If ratio increase means more output can be produced using the amount of particular input, or an amount of particular input can be produced by using less input. Two things count in the Malmquist index measurement, which is the catch-up effect and frontier shift effect. The catch-up effect measures the level of efficiency change relatively from period 1 to period 2. Meanwhile, the frontier shift effect measures the level of technological change, which is a combination of input and output from period 1 to period 2. The frontier shift effect is often called as innovation effect.

MPI is a bilateral index used to compare production technology of two economic substances and the basis of the production function concept that measures maximum production function with determined input limitation. MPI has several advantageous 
characteristics. First, this index is a non-parametric method; therefore, it doesn't need specification of production function form. Second, MPI doesn't need to assume production unit economy behavior, such as cost minimization or profit maximization. So it is really useful if producers are different or unknown. Third, this index measurement doesn't need a price of input and output data which is often unavailable. Fourth, MTFPI can be composed of two components which are EFFCH and TECHCH. According to Avenzora (2008), this is very useful because the analysis can be done more specifically based on components. Positive EFFCH (positive efficiency change) is evidence that efficiency change near the frontier, while positive TECHCH (positive technological change) is known that technological change as innovation. EFFCH can then be composed of two components: PECH and SECH (Fare et al., 1994).

To limit the research scope, the data bank taken is from 2010 until 2019. This research uses output and input variables and uses general and administrative cost, fixed asset, and total saving as an input variable. Output variables use the total loan, securities investment, and other income.

Table 2 below explains input and output data in MPI during 2010-2019. This research refers to bank function as an intermediation institution, so this research put total saving as input variables.

Tabel 2. Productivity input and output variables (in a million rupiahs)

\begin{tabular}{lrrrrrr}
\hline & $\begin{array}{r}\text { General } \\
\text { and Admin }\end{array}$ & $\begin{array}{r}\text { Fixed } \\
\text { Assets }\end{array}$ & $\begin{array}{r}\text { Total } \\
\text { Deposit }\end{array}$ & $\begin{array}{r}\text { Total } \\
\text { Finance }\end{array}$ & $\begin{array}{r}\text { Securities } \\
\text { and } \\
\text { Investment }\end{array}$ & $\begin{array}{r}\text { Other } \\
\text { Income }\end{array}$ \\
\hline Mean & 264,956 & 418,275 & $1,927,811$ & $6,454,018$ & $1,999,999$ & 174,106 \\
Std.Dev & 360,771 & 751,698 & $3,360,047$ & $10,563,686$ & $3,565,831$ & 306,921 \\
Maximum & $1,507,041$ & $3,357,284$ & $16,637,027$ & $42,865,000$ & $21,088,128$ & $1,866,238$ \\
Minimum & 3,339 & 1,794 & 1 & 4,802 & 492 & 969 \\
\hline
\end{tabular}

During the research sample period in 2011 until 2019, as many as 84 banks show an average score of 264,956 million. It indicates that the bank as a whole during research spent cost that much from all bank assets. The average fixed asset is 418,275 million, and high GA value reflects a high disparity inter bank operation. The amount of fixed assets between the highest and the lowest score is still very different; therefore, the bank needs to increase assets to work optimally. As an intermediation institution, there are still banks that have quite a low amount of savings. It indicates that the manager hasn't managed the banking function optimally, even though, as a whole, the average saving is 3,360 billion.

Output variable, a total loan given to related parties, shows an average score of $6,454,018$ million. It indicates that the total loan given by the bank from the total assets owned is 6,454,018 million. Funding distribution that is higher than saving indicates that Islamic bank gives more comfort for society in terms of funding distribution. The average investment also has a high value, of 1.999 billion, with the lowest investment of 492 million. Meanwhile, banking also needs to increase the amount of another income, which is about 174 billion.

Table 3 indicates productivity change in each research sample bank in average has achieved productive level, this is shown from the average of achievement that has change score of Total Productivity Factor (TFPCH) is quite optimal which is shown from the average of 1.024, this result is in accordance with the score of Technical Efficiency Change (EFFCH) which is valued 1.016 and scale efficiency 1.010 which means Islamic bank in Indonesia is assessed has managed its activity efficiently which 
is shown by the capability of managing input and output. There was a productivity decline in several banks during research, such as bank samples 1,3,6 caused by Technological Change (TECHCH). It means the decline in productivity was due to the technology factor and not because of the efficiency factor; therefore, issue related to technological advancement on each bank becomes important. On the contrary, the decrease in samples 8 dan 9 happened because the corporation could not efficiently manage bank input and output. It is shown from the low score of EFFCH in both samples compared to the technological factor (TECHCH).

Table 3. Malmquist Index summary of firm means

\begin{tabular}{crrrrr}
\hline Firm & EFFCH & TECHCH & PECH & SECH & TFPCH \\
\hline 1 & 0.960 & 0.971 & 1.000 & 0.960 & 0.932 \\
2 & 1.202 & 0.921 & 1.000 & 1.202 & 1.108 \\
3 & 1.000 & 0.941 & 1.000 & 1.000 & 0.941 \\
4 & 1.012 & 1.503 & 1.008 & 1.004 & 1.522 \\
5 & 1.129 & 0.943 & 1.096 & 1.030 & 1.055 \\
6 & 0.987 & 0.849 & 0.988 & 0.999 & 0.838 \\
7 & 1.092 & 1.078 & 1.090 & 1.002 & 1.177 \\
8 & 0.916 & 1.020 & 0.930 & 0.985 & 0.935 \\
9 & 0.393 & 0.903 & 0.968 & 0.970 & 0.848 \\
10 & 0.975 & 1.052 & 1.000 & 0.975 & 1.026 \\
11 & 1.000 & 1.034 & 1.000 & 1.000 & 1.034 \\
\hline Mean & 1.016 & 1.007 & 1.006 & 1.010 & 1.024 \\
\hline
\end{tabular}

Information: EFFCH (Technical Efficiency Change); TECHCH (Technological Change); PECH (Pure Technical Efficiency Change); SECH (Scale Efficiency Change); TFPCH (Total Factor Productivity Change)

Meanwhile, on scale efficiency (SECH) and pure technical efficiency (PECH) result indicates that scale efficiency exceeds pure technical efficiency. Suppose inefficiency change most are due to pure efficiency (PECH), not scale efficiency $(\mathrm{SECH})$. In that case, it shows that the bigger unit (trust) size it will give more disadvantage for productivity performance. In other words, a high score on SECH indicates that management is competent in using input resources effectively.

The test result shows that banking productivity level is more affected by performance efficiency and not technology. Rodoni et al. (2017) conclude that Indonesia's contributor to banking productivity is not the technological aspect but managerial performance.

Table 4 shows bank productivity change in Islamic Bank in Indonesia during the research period in average has achieved productive level, this is shown from the average score of Total Productivity Factor (TFPCH) assessed quite optimum which is seen from the average of 1.024, this result is in accordance with Technical Efficiency Change $(\mathrm{EFFCH})$ valued 1.016 which means Islamic banking in Indonesia has managed its activity efficiently that is indicated by the capability of managing input and output. Efficiency fluctuation on the General Islamic bank in Indonesia during the research period could be due to an economic crisis. During the research, there is also a decrease in productivity in several years, such as 2011/2012, 2012/2013, 2013/2014, and 2016/2017, because of Technological Change (TECHCH) during those years. Therefore, technological advancement that can support Islamic bank activity is needed, such as easier Anjungan Tunai Mandiri (ATM) access, mobile banking, internet banking, and financial technology improvement 
Table 4. Malmquist Index summary of annual means

\begin{tabular}{lrrrrr}
\hline Year & EFFCH & TECHCH & PECH & SECH & TFPCH \\
\hline $2010 / 2011$ & 0.988 & 1.177 & 1.082 & 0.913 & 1.163 \\
$2011 / 2012$ & 0.929 & 0.876 & 1.039 & 0.894 & 0.814 \\
$2012 / 2013$ & 0.981 & 0.917 & 0.946 & 1.037 & 0.899 \\
$2013 / 2014$ & 1.002 & 0.888 & 1.018 & 0.984 & 0.889 \\
$2014 / 2015$ & 1.131 & 1.008 & 1.041 & 1.087 & 1.140 \\
$2015 / 2016$ & 0.917 & 1.297 & 0.987 & 0.930 & 1.189 \\
$2016 / 2017$ & 1.234 & 0.518 & 0.931 & 1.325 & 0.639 \\
$2017 / 2018$ & 1.127 & 1.457 & 1.083 & 1.041 & 1.643 \\
$2018 / 2019$ & 0.888 & 1.291 & 0.944 & 0.940 & 1.147 \\
\hline Mean & 1.016 & 1.007 & 1.006 & 1.010 & 1.024 \\
\hline Information: EFFCH (Technical Efficiency Change); TECHCH (Technological Change); PECH (Pure \\
Technical Efficiency Change); SECH (Scale Efficiency Change); \\
TFPCH (Total Factor Productivity Change)
\end{tabular}

The PECH and SECH indices are a decomposition of the EFFCH index; the results show that SECH and not PECH mainly cause growth in the EFFCH value. The composition of SECH of 1,010 shows that Islamic banks can manage and utilize the available inputs to produce maximum output. The PECH value of 1,006 explains that Islamic banks' operational costs can be controlled due to increased managerial efficiency. The high EFFCH result shows that society's interest in Islamic banking increases because of the higher level of society literacy about Islamic banking, especially the awareness of riba's impact.

The result from the Malmquist index analysis is very interesting. The improvement of Islamic bank productivity is more affected by technical efficiency changes $(\mathrm{EFFCH})$ and scale efficiency $(\mathrm{SECH})$, a decomposition of EFFCH. Besides, the decrease in several years or several corporations happens because of the decrease in technological change; therefore, banking service improvement, especially technology utilization, is needed. This finding is following the research by Rusydiana, Laila, \& Sudana (2019); Rusydiana, (2018); Kamarudin, Hue, Sufian, Anwar, \& Aina (2017); Rodoni, Salim, Amalia, \& Rakhmadi, (2017); Bahrini (2015); Sufian. \& Habibullah (2014). However, these findings are not in line with Otaviya \& Rani's (2020) research, which shows that technological changes influence Islamic banks' productivity.

\section{CONCLUSIONS AND RECOMMENDATIONS}

\section{Conclusions}

Islamic bank productivity level test results in Indonesia using Malmquist Productivity Index shows that productivity growth index on average is fulfilled, especially in the last years of research shows that an efficiency factor supports productivity change. The other result in certain years states that the change in productivity decrease also affected by technological decrease, so Islamic bank is expected to increase the usage of technology dynamically, safe, and reliable. Therefore production activity can move positively. The increased amount of network also needs to be done to reach broader society. Besides that, product diversification, especially in funding, must be done.

\section{Recommendations}

This research has implications for industry players to carry out bank operations more productively by managing inputs as best as possible and increasing the resulting 
output. For OJK, the results of this research are expected to serve as a guide for future banking policy direction so that banks can continue to improve, especially in the use of technology to maintain the level of productivity of Islamic Banks in Indonesia.

\section{ACKNOWLEDGMENTS}

The researcher expresses gratitude toward all parties that have helped in this research. This research could be carried out because of the support from Direktorat Penelitian dan Pengabdian kepada Masyarakat (Directorate of Research and Community Service), Direktorat Jenderal Penguatan Penelitian dan Pengembangan (Directorate General of Research and Development Strengthening), Kementerian Riset dan Teknologi/Badan Riset dan Inovasi Nasional (Ministry of Research and Technology/National Research and Innovation Agency) of Republik Indonesia.

\section{REFERENCES}

Abbas, M., Hammad, R. S., Elshahat, M. F., \& Azid, T. (2015). Efficiency, productivity and Islamic banks: An application of DEA and Malmquist index. Humanomics, 31(1), 118-131. https://doi.org/10.1108/H-03-2013-0022

Avenzora, A., \& Jossy P., M. (2008). Analisis Produktivitas dan Efisiensi Industri Tekstil dan Produk Tekstil di Indonesia Tahun 2002-2004. [Master's Thesis] Universitas Indonesia.

Bahrini, R. (2015). Productivity of MENA Islamic banks: a bootstrapped Malmquist index approach. International Journal of Islamic and Middle Eastern Finance and Management, 8(4), 508-528. https://doi.org/10.1108/IMEFM-11-2014-0114

Basri, M. F., Muhamat, A. A., \& Jaafar, M. N. (2018). The efficiency of Islamic banks in Malaysia: Based on DEA and Malmquist productivity index. Journal of Emerging Economies and Islamic Research, 6(3), 15. https://doi.org/10.24191/jeeir.v6i3.8784

Coelli, T. J., Rao, D. P., O’Donnell, C. J., \& Battese, G. E. (2005). an Introduction to Efficiency and Productivity Analysis (2nd ed.). New York: Springer Science + Business Media Inc.

Griffel-Tatje, E. and Lovell, C. A. K. (1996). Deregulation and productivity decline: the case ofSpanish saving banks. European Economic Review, 40(No. 6), 1281-1303.

Hadad, M. D., Hall, M. J. B., Kenjegaliev, K. A., Santoso, W., \& Simper, R. (2011). Productivity changes and risk management in Indonesian banking: A Malmquist analysis. Applied Financial Economics, 21(12), 847-861. https://doi.org/10.1080/09603107.2010.537636

Kalluci, Irini. 2018. Albanian Banking Sector Productivity Using Malmquist Index. Research Journal of Finance and Accounting. Vol 9, No. 12.

Kamarudin, F., Hue, C. Z., Sufian, F., \& Anwar, N. A. M. (2017). Does Productivity of Islamic Banks Endure Progress or Regress? Empirical Evidence using Data Envelopment Analysis Based Malmquist Productivity Index. Humanomics (Vol. 33). https://doi.org/10.1108/H-08-2016-0059

Kumbhakar, S.C. \& Lovell, C. a. K., 2000. Stochastic frontier analysis. Stochastic frontier analysis, 69, p.680.

Neupane, B. (2013). Efficiency and Productivity of Commercial Banks in Nepal: A Malmquist Index Approach. Asian Journal of Finance \& Accounting, 5(2), 220. https://doi.org/10.5296/ajfa.v5i2.4326

Octrina, F., Primiana, I., Anwar, M., Herwany, A., \& Rusnoto Susanto, M. (2019). Malmquist Index Productivity of Indonesian Bank: Based on Commercial Bank Business Group. International Journal of Recent Technology and Engineering, 
$8(1 \mathrm{C} 2)$.

Octrina, F., Setiawati, R., Asnawi, A., \& Putri, R. K. (2020). Produktivitas Perbankan Indonesia dengan Pendekatan Malmquist Index Productivity. Jurnal Sain Manajemen, 2(1), 45-55.

Otaviya, S. A., \& Rani, L. N. (2020). Productivity and Determinant of Islamic Banks Evidence From Indonesia. Journal of Islamic Monetary Economics and Finance, 6(1), 189-212. https://doi.org/10.21098/jimf.v6i1.1146

Rani, L. N., Widiastuti, T., \& Rusydiana, A. S. (2018). Comparative Analysis of Islamic Bank's Productivity and Conventional Bank's in Indonesia Period 2008-2016. 1st International Conference on Islamic Economics, Business and Philanthropy. Bandung

Raphael, G. (2013). A DEA-Based Malmquist Productivity Index approach in assessing performance of commercial banks: Evidence from Tanzania. European Journal of Business and Management, 5(6), 2222-2839.

Rodoni, A., Salim, M. A., Amalia, E., \& Rakhmadi, R. S. (2017). Comparing Efficiency and Productivity in Islamic Banking: Case Study Indonesia, Malaysia and Pakistan. Al-Iqtishad: Journal of Islamic Economics, 9(2), 227-242. https://doi.org/10.15408/aiq.v9i2.5153

Rusydiana, A. S. (2018). Indeks Malmquist untuk Pengukuran Efisiensi dan Produktivitas Bank Syariah di Indonesia. Jurnal Ekonomi Pembangunan, 26(1), 47-58. https://doi.org/10.14203/jep.26.1.2018.47-58

Rusydiana, A. S., Laila, N., \& Sudana, S. (2019). Efisiensi dan produktivitas industri perbankan pada sistem moneter ganda di Indonesia. Jurnal Siasat Bisnis, 23(1), 50-66. https://doi.org/10.20885/jsb.vol23.iss1.art5

Sellers-rubio, R., \& Mas-ruiz, F. (2007). An empirical analysis of productivity growth in retail services : evidence from Spain. International Journal of Service Industry Management, 18(1), 52-69. https://doi.org/10.1108/09564230710732894

Sufian., F., \& Habibullah., M. S. (2014). Banks' Total Factor Productivity Growth in a Developing Economy: Does Globalisation Matter? Journal of International Development, 26, 821-852.

Sufian, F. (2009). Sources of TFP growth in the Malaysian Islamic banking sector. Service Industries Journal, 29(9), 1273-1291. https://doi.org/10.1080/02642060801911128

Suzuki, Y., \& Sastrosuwito, S. (2011). Efficiency and Productivity Change of the Indonesian Commercial Banks. IACSIT Press, 7, 10-14.

Usman, N., Andriyani, L., \& Pambuko, Z. B. (2019). Productivity of Islamic Banks in Indonesia: Social Funds versus Financial Funds. Journal of Asian Finance, $\begin{array}{llll}\text { Economics } \quad \text { Bnd } & \text { Business, } & 115-122 .\end{array}$ https://doi.org/10.13106/jafeb.2019.vol6.no3.115

Yildirim, I. (2015). Financial Efficiency Analysis in Islamic Banks: Turkey and Malaysia Models. $\quad$ Pressacademia, 2(3), 289-289. https://doi.org/10.17261/pressacademia.2015312956

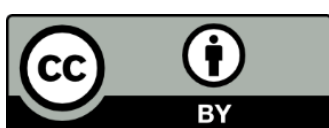

(C) 2021 by the authors. Licensee JPPD, Indonesia. This article is an open-access article distributed under the terms and conditions of the Creative Commons Attribution (CC BY) license (http://creativecommons.org/licenses/by/4.0/). 